\title{
Correlation between CYP2D6*10 Gene Mutation, and Structure and Function of its Encoding Protein
}

\author{
Ju-yi Li ${ }^{1}$, Xiu-fang Wang ${ }^{2}$, Zhao-qing Zhang ${ }^{2}$, Yong-gang Chen ${ }^{1}$, Ji-li Zou ${ }^{1}$, \\ Xiong Wang ${ }^{1}$ and Jin-hu Wu ${ }^{1 *}$ \\ ${ }^{1}$ Department of Pharmacy, ${ }^{2}$ Department of Rehabilitation, The Third Hospital of Wuhan, Wuhan, Hubei Province, 430060 \\ China. \\ *For correspondence: Email: lisan727@163.com
}

Received: 30 August 2013

Revised accepted: 16 January 2014

\begin{abstract}
Purpose: To investigate the gene polymorphism of CYP2D6*10 (C188T) in the Hui people and study its correlation between CYP2D6*10 gene mutation and structure and function of its encoding protein.

Methods: 150 unrelated Hui ethnic group volunteers participated in this study. A total of $500 \mu \mathrm{L}$ heparin-treated blood from each volunteer was extracted with the TIANGEN DNA Mini Kit. Allele specific amplification PCR and Gene sequencing were used to detect the CYP2D6 alleles *10. Bioinformatics and computer modeling methods were used to predict the spatial structure and function of the protein encoded by the wild type gene and mutant gene.

Results: The mutation frequency of C188T allele (T) of CYP2D6*10 in Ningxia Hui people was $47.5 \%$, compared with Turkish (14.5\%), Ethiopia (8.6\%), Spanish (1.9\%), and they were significantly different, $(p<0.01 ;)$ The result from ProtParam shows that mutant protein was more unstable than the wild-type protein. The isoelectric point, molecular weight and hydrophilicity were similar in terms of mutant protein and wild-type protein. Analysis of the gene sequence of CYP2D6*10 using DNAStar/Protein software indicates that the mutant protein had one more Gamier-Robson Turn while MotifScan analysis showed that the wild-type protein had 2 P450 enzyme activation sites and that there was none in the mutant protein. Analysis using SignalP demonstrated that the wild-type protein had signal peptide while the mutant protein had none. Analysis using TMHMM Server showed that both of them had a transmembrane region. The foregoing differences between the mutant protein and the wild-type protein could influence the activity of CYP2D6.

Conclusion: Gene mutation can change the spatial structure and function of CYP2D6. This change may be the main reason for the decreased activity of the enzyme.
\end{abstract}

Keywords: Polymorphism, CYP2D6, Mutant, Allele, Protein, Gene, Bioinformatics, Personalized medicine.

Tropical Journal of Pharmaceutical Research is indexed by Science Citation Index (SciSearch), Scopus, International Pharmaceutical Abstract, Chemical Abstracts, Embase, Index Copernicus, EBSCO, African Index Medicus, JournalSeek, Journal Citation Reports/Science Edition, Directory of Open Access Journals (DOAJ), African Journal Online, Bioline International, Open-J-Gate and Pharmacy Abstracts

\section{INTRODUCTION}

CYP2D6 is responsible for the metabolism of many endogenous as well as exogenous compounds [1]. It metabolizes more than $25 \%$ of all therapeutic drugs [2]. The metabolism of these substrates is highly dependent on the amount of active CYP2D6 enzymes expressed in the liver. At present, more than 150 relevant alleles of CYP2D6 gene have been identified [3], with varying frequencies between ethnic groups [4].There is a large inter-individual variation in the enzyme activity of CYP2D6, resulting in enzymes with high, low, or no activity $[5,6]$. 
There is a close relationship between CYP2D6 genotype and phenotype [7-9]. The CYP2D6*10 allele. which results in a P34S substitution (C188T) change the protein's primary structure encoded by CYP2D6, thereby influencing the protein's advanced structure and the active CYP2D6 enzyme. Genetic diagnosis can be used to predict an individual's phenotype reliably and may facilitate improved drug efficacy and diminished risk for adverse drug reactions $[10,11]$.

Ningxia Hui nationalities are a special population in China. There is no report on mutation frequency of C188T allele (T) of CYP2D6*10 in Ningxia Hui nationalities. Therefore, in this study, 150 healthy people were selected to detect the frequency of C188T allele of CYP2D6 as well as analyze the differences in spatial structure and function between the wild type protein and the mutant protein using bioinformatics methods. This will provide the theoretical basis for applying gene polymorphism to guide clinically personalized medicine.

\section{EXPERIMENTAL}

\section{Subjects}

One hundred and fifty (150) unrelated Hui ethnic group volunteers participated in this study after giving written informed consent. They were healthy volunteers recruited during their routine check-up in Yinchuan, China. This study was approved by Ethics Committee of Ningxia Autonomous Region people's Hospital (approval ref. no. 20110920)[12]. A total of $500 \mu \mathrm{L}$ heparintreated blood from each volunteer was extracted with the TIANGEN DNA Mini Kit.

\section{Detection of CYP2D6*10}

Allele specific amplification(ASA) PCR and DNA sequencing were developed to detect the CYP2D6 alleles *10 [13], its primer is as follows, P1: 5'-GAGCCCATTTGGTAGTGAGGCAGGT-3', P2: 5-GAGACCCAGCCTCCTGATCGTGG-3', P3: 5'-GGGGGCCTGGTGA-3', P4: 5'-GGGGG CCTGGTGG-3

\section{Comparison of protein structure and function}

Using bioinformatics analysis software was used to predict and analyze the similarities and differences of the mutant and wild-type protein structure and function encoded by the CYP2D6*10 gene.
Table 1: Tools for bioinformatics

\begin{tabular}{lll}
\hline S/N & Name & Copyright \\
\hline 1 & DNAStar & Dr.Steve ShearDown R.P.M.S \\
2 & Internet/NCBI// & http://www.ncbi.nlm.nih.go/ \\
3 & Internet/ & http://www.expasy.ch/ \\
& EXPAY & http://www.cbs.dtu.dk/services/Sign \\
4 & SignalP & $\begin{array}{l}\text { alP } \\
\end{array}$ \\
5 & TMHMM Serverhttp://www.cbs.dtu.dk/services/TMH \\
& & $\begin{array}{l}\text { MM/l } \\
\text { http://hits.isb-sib.ch/cgi- } \\
\text { bin/PFSCAN }\end{array}$ \\
\hline
\end{tabular}

\section{Statistical analysis}

Allele frequency was determined via direct counting and the standard goodness-of-fit test was used to test the Hardy-Weinberg equilibrium. The distribution of genotypes in the study was obtained by Chi-square test. All statistical analyses were performed using SPSS software, and significance was defined as $p<0.05$.

\section{RESULTS}

\section{The product of PCR}

The mutation frequency of allelic genes of CYP2D6*10 in the region of Ningxia Hui nationality was $47.5 \%$ (Fig 1), compared to Turkish (14.5\%), Ethiopia (8.6\%), and Spanish $(1.9 \%)$ [14]; this is significantly different, $(p<$ 0.01 ), as shown in Table 2.

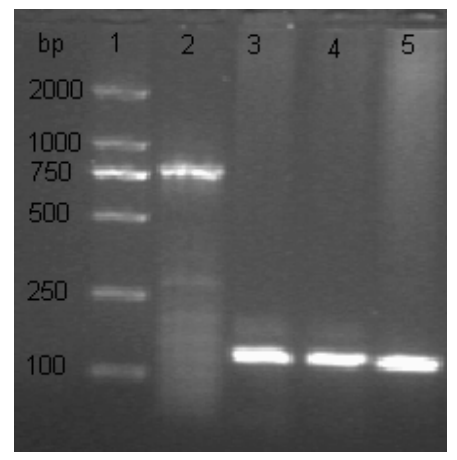

Figure 1: The product of PCR

1. DNA standard molecular weight marker; 2. The total length CYP2D6*10; 3. CYP2D6*10 mutant homozygote; 4. CYP2D6*10 heterozygote; 5. CYP2D $6 * 10$ wild homozygote

\section{Fundamental nature of the protein encoded} by the CYP2D6*10 gene

Analysis of the gene sequence of CYP2D6*10 using DNAStar/Protein software indicates that CYP2D6*10 ( $T$ instead of C) produced the amino acid " $S$ " instead of " $P$ ". When the differences 
Table 2: Frequencies of CYP2D6*10 genotype compared for different ethnic groups

\begin{tabular}{lllllll}
\hline Population & $\mathbf{n}$ & \multicolumn{2}{l}{ Allele frequency (\%) } & $\mathbf{C C}(\%)$ & $\mathbf{C T}(\%)$ & TT(\%) \\
\hline Hong Kong Chinese & 119 & & 46.2 & 4.2 & 30.3 & 41.2 \\
Chinese Han & 223 & 51.6 & & 5.8 & 27.8 & 24.2 \\
China Miao & 100 & 47.5 & 31.0 & 43.0 & 26.0 \\
Korean & 152 & 51.0 & 26.0 & 45.0 & 28.0 \\
Japanese & 98 & 40.8 & 18.4 & 33.7 & 17.3 \\
Ethiopia & 122 & 8.6 & 9.0 & - & - \\
Turkish & 100 & 14.5 & 75 & 21 & 4 \\
Spanish & 105 & 1.9 & - & - & - \\
NingXia Hui & 150 & 47.5 & 32 & 40.7 & 27.3 \\
\hline
\end{tabular}

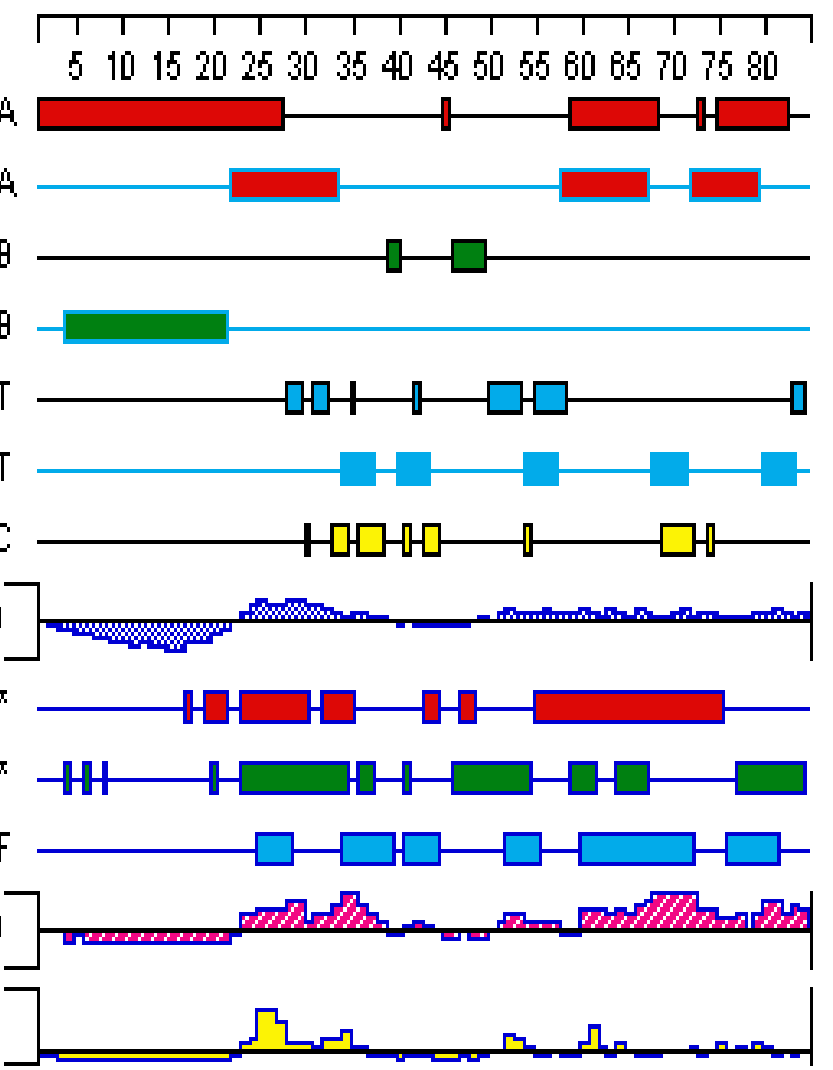

口Scale

口Apha, Riegions - Giamier- Riobson

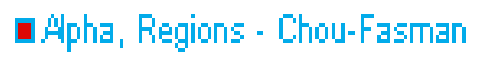

口Eta, Regions - Gamier-Rotison

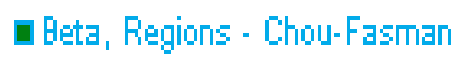

口Tum, Regions - Gamier-Riotson

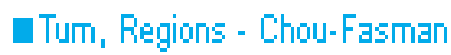

uCoil, Riggons - Gamier-Fötson

o Hydrophilisity Plot - Gyte-Coolittle

口Apha, Amphipathic: Regions - Esenterg

口 Beta, Amphipathic: Regions - Esenterg

qFlexible Riegions - Kaplus-schiulz

ar Antigenis: Index - Jameson-libolf

uSurtiace Probability Plót - Eтiri

\section{Figure 2: CYP2D6*10 wild-type}

between wild-type protein and mutant protein of CYP2D6*10 are compared using ProtParam (ExPASy), it is evident that the instability index of mutant protein is higher than wild-type protein, although both were above the threshould 40 and were neutral in solution.

\section{Prediction of the protein's second structure and activation sites}

Analysis of the gene sequence of the amino acids encoded by the PCR product made by DNAStar/Protean software indicate that the mutant protein had one more Gamier-Robson Turn in the 33rd site, as shown in Figures 2 and
3. MotifScan analysis shows that the wild-type protein possessed 2 P450 enzyme activation sites while the mutant protein had none.

\section{Post-translational modification and structural features of sequence}

Analysis with SignalP demonstrated that the wildtype protein had signal peptide while mutant protein did not have. The cleavage site was between the 30th and 31st (between RWA and AR). However, anaysis with TMHMM Server v. 2.0 shows that both of them had a transmembrane region. 


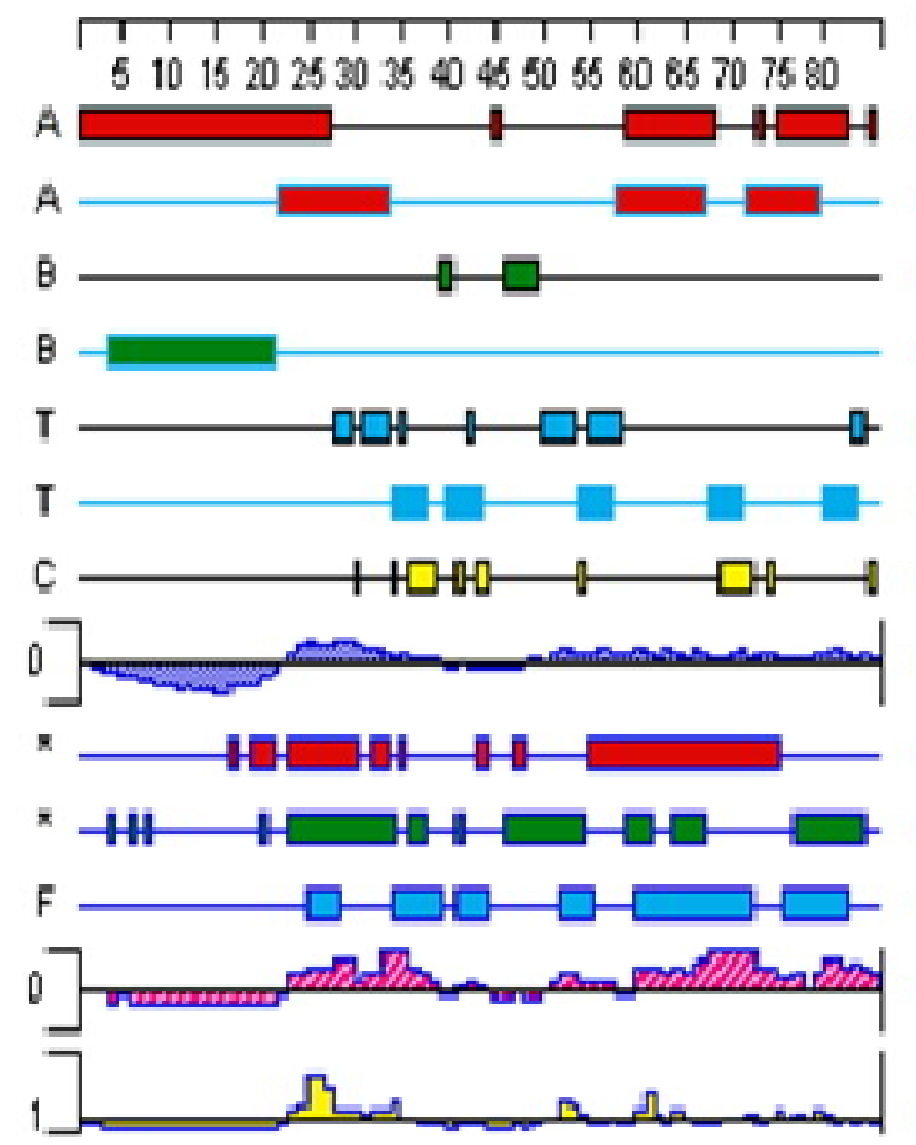

Q Soale

口Apha, Regions - Garmier-Robson

I Apha, Regions - Chou- Fasman

口 Beta, Regons - Gamier-Robson

I Beta, Regonos - Chou-Fasman

uTum, Regions - Gamier-Robson

n Tum, Regions - Chou-Fasmin

q Coil, Regions - Gamier Robson

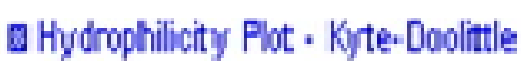

Apha, Amphipathic Regions - Esenberg

Beta. Amphipothio Regions - Esenberg

a Flexible Regions - Karplus-schula

a Antigenis index - Jameson-Wolf

¿ Surface Probability Plot - Eniri

Figure 3: CYP2D6*10 mutant

\section{DISCUSSION}

Bioinformatics is a art and science which use calculations in biological research areas such as genomics, transcriptomics, proteomics, genetics and evolution; in other words, bioinformatics acquire and interpret biological data using computing and analytical tools.

Cytochrome P4502D6 (CYP2D6) is the most polymorphic P450 oxidative metabolism enzyme system. Several studies have reported the association between the lipid-lowering efficacy of simvastatin and genetic polymorphisms of CYP2D6. Nordin found that a significant correlation between LDL-C reduction and reduced expression of CYP2D6 [15]. Mulder found that the cholesterol-lowering effect of simvastatin was influenced by CYP2D6 polymorphism [16]. However, Prueksaritanont concluded that the efficacy of simvastatin is not influenced by CYP2D6 polymorphism [17].

The analytic result of online protein assayer has shown that the mutant protein is more instable than wild-type protein and the instability of the mutant protein is related to the reduction of enzyme activity. Analysis of the gene sequence of CYP2D6*10 made by DNAStar/Protein software indicated that the mutant protein has one more Gamier-Robson Turn in the 33rd site. The result also indicate that the mutation site of CYP2D6*10 (C188T) in the spatial structure may affect the spatial arrangement of other amino acids, which will, in turn, alter the structure and function of CYP2D6*10 and lead to the decline of enzyme activity. It also revealed that the wildtype protein possesses 2 P450 enzyme activation sites while the mutant protein had none, based MotifScan analysis. It has also been shown that the wild-type protein belongs to the family of $\mathrm{P} 450$ protein enzyme, which might become potential target drugs whereas the mutant protein having lost this functional site may result in the decline of its activity.

As part of amino acid sequence in one end of protein, signal peptide could be used for guiding the target protein to precisely locate in the cell by getting through the membrane of the cellorganelle. C-score shows that the mutant protein has no signal peptide whereas the wild-type protein does. Internal signal peptide sequence indicates that the wild-type protein is a secreted protein while the mutant protein having lost this function may exert an influence on its enzyme activity. However, analysis of TMHMM Server 
showed that both of them had a transmembrane region.

\section{CONCLUSION}

Our results suggest that the CYP2D6 gene polymorphism determines its enzyme activity and might influence an individual's behavior. In future, clinicians could choose rational drugs and apply the most suitable dosage to reduce and avoid the occurrence of adverse reactions so as to achieve an ideal "personalized treatment".

\section{ACKNOWLEDGEMENT}

This research was supported by Natural Science Foundation of Ningxia (no. NZ07109); Health Department of Key Research Projects in Ningxia (no. W200707).

\section{REFERENCES}

1. Kimura S, Umeno M, Skoda RC, Meyer UA, Gonzalez FJ. The human debrisoquine 4-hydroxylase (CYP2D) locus: sequence and identification of the polymorphic CYP2D6 gene, arelated gene, and a pseudogene. Am J Hum Genet 1989; 45: 889-904.

2. Eichelbaum $M$, Ingelman-Sundberg $M$, Evans WE. Pharmacogenomics and in dividualized drug therapy. Annu Rev Med 2006; 57: 119-137.

3. Arneth B, Shams M, Hiemke C, Härtter S. Rapid and reliable genotyping procedure for detection of alleles with mutations, deletion, or/and duplication of the CYP2D6 gene. Clin Biochem 2009; 42: 1282-1290.

4. Bradford LD. CYP2D6 allele frequency in European Caucasians, Asians, Africans and their descendants. Pharmacogenomics 2002; 3: 229-243.

5. Zhou SF. Polymorphism of human cytochrome P450 2D6 and its clinical 353 significance: part I. Clin Pharmacokinet.2009a; 48: 689-723.

6. Zhou SF. Polymorphism of human cytochrome P450 2D6 and its clinical 355 significance: part II. Clin Pharmacokinet 2009b; 48: 761-804.
7. Sachse C, Brockmöller J, Bauer S, Roots I. Cytochrome P450 2D6 variants in a Caucasian population: allele frequencies and phenotypic consequences. Am J Hum Genet 1997; 60: 284-295,.

8. Dalén P, Dahl ML, Bernal Ruiz ML, Nordin J, Bertilsson L. 10-Hydroxylation of nortriptyline in white persons with $0,1,2,3$, and 13 functional CYP2D6 genes. Clin Pharmacol Ther 1998; 63: 444-452.

9. Griese EU, Zanger UM, Brudermanns U, Gaedigk A, Mikus G, Mörike $K$, Stüven $T$, Eichelbaum M.. Assessment of the predictive power of genotypes for the in-vivo catalytic function of CYP2D6 in a German population. Pharmacogenetics 1998; 8: 15-26

10. Sistonen J, Fuselli S, Levo A, Sajantila A. CYP2D6 genotyping by a multiplex primer extension reaction. Clin Chem 2005; 51: 1291-1296.

11. Lindpaintner $K$. Pharmacogenetics and the future of medical practice. Br J Clin Pharmacol 2002; 54: 221 230.

12. World Medical Association. World Medical Association Declaration of Helsinki: Ethical Principles for Medical Research Involving Human Subjects. Seoul: From the 59th World Medical Association Assembly, 2008. http://www.wma.net/en/30publications/10policies/b3/ 17c.pdf.

13. Garcia-Barceló M, Chow LY, Chiu HF, Wing YK, Lee DT, Lam KL. Waye MM. Genetic analysis of the CYP2D6 locus in a Hong Kong Chinese population. Clin Chem 2000; 46: 18-23.

14. Ji L, Pan S, Wu J, Marti-Jaun J, Hersberger M. Genetic polymorphisms of CYP2D6 in Chinese mainland. Chin Med J 2002; 115: 1780-1784.

15. Nordin C, Dahl ML, Eriksson M, Sjoberg S. Is the cholesterol-lowering effect of simvastatin influenced by CYP2D6 polymorphism? Lancet 1997; 350: 2930.

16. Mulder $A B$, van $L i j f H J$, Bon $M A$, van den Bergh $F A$, Touw DJ, Neef C, Vermes I.. Association of polymorphism in the cytochrome CYP2D6 and the efficacy and tolerability of simvastatin. Clin Pharmacol Ther 2001; 70: 546-551.

17. Prueksaritanont $T, M a B, Y u N$. The human hepatic metabolism of simvastatin hydroxy acid is mediated primarily by CYP3A, and not CYP2D6. Br J Clin Pharmacol 2003; 56: 120-124. 